\title{
An Overview of Application of E-Resources as Strategies for Enhancing Effective Library Services in Academic Libraries
}

\author{
Olabisi Iyabode Moruwawon \\ Department of Vocational and Technical Education (Library and Information Science Unit) \\ Faculty of Education, Ekiti State University, Ado-Ekiti, Ekiti State, Nigeria. \\ bisimoruwawon@gmail.com
}

\begin{abstract}
Libraries of the present age cannot grow without proper application of e-resources (electronic resources) and ICT facilities to its services. The advent of new technology has drastically transformed the way and manner information professionals provide services to their clients. Digital libraries are the new developments in the evergrowing technological era. E-resources are conveniently accessible outside the four walls of the library. This paper focuses on the way e-resources can be applied as strategies for enhancing effective library services. It also considers the benefits and challenges of applying e-resources to library services. Literature review method was adopted in the study by randomly reviewing articles that were related to the study. The study showed that application of e-resources is very paramount to library services and as such every impediment to its effective use should be taken into considerations.
\end{abstract}

Keywords: Application; e-resources; strategy; library services; academic library

DOI: $10.7176 / \mathrm{IKM} / 10-2-09$

Publication date: March $31^{\text {st }} 2020$

\subsection{Introduction}

Electronic information resources (e-resources) involves any information resources that can be accessed through the internet. It is an organized collection of digitized materials or its holdings in the digital form which can be accessible by a computer on the network by using TCP/IP or other protocol (Hungwa, \& Ramatu 2013). Eresources are taking possession of a significant aspect of global literatures. The role of the library and library staff as the traditional reader advisor has changed due to need for intermediation for users and has become germane in the face of information proliferation. Academic library staff are discovering ways to respond to expanded competition for resources. E-resources have become integral part of the information resources for academicians and researchers and can substitute print resources. Generally, it is apparent that the print age is paving way for electronic information resources (Kelefa, Emmanuel, \& Esther, 2017).

With the rapid development of electronic publishing, libraries are not only acquiring reading materials such as printed journals and books, but also arranging for providing access to various learning resources in electronic form. The digitization of information in print media has brought a new concept altogether in all fields of human life. The library and information services in the $21^{\text {st }}$ century is fast changing. The rapid emergence and development of electronic information technologies makes it possible to envision radically different ways of organizing the collections and services the library has traditionally provided. The application of computers to information processing has brought several products and services to the scene, consequently the academic community has undergone tremendous changes during these years. Libraries have witnessed great changes in recent years both in their collection development and in their service structures. Scholarly information and communication are significantly affected by the instantaneous development in communication technologies. Information needs and retrieval are effectively and efficiently met through e-resources such as internet, OPACs, CD-ROM.

Academic libraries are used mostly for research work thus have to move towards digital e-resources for easy access. Advancements in technologies have changed the way information is acquired, stored, retrieved and disseminated. It has equally changed the way library services are rendered. Libraries have transformed into virtual libraries where books and journals have changed into e-books and e-journals. E-resources are easily accessible in remote areas and thus increased the global dissemination of information. E-resources have solved storage problems and control the flood of information, print sources are being digitized in order to promote and 
engender utility (Jasper, et al 2016). Electronic information sources can be seen as the most recent development in information technology and are among the most powerful tools for enhancing effective library services. They noted that users find electronic resources attractive and use them more heavily than print sources as a result, libraries in response to the needs of their users are increasingly making electronic information resources available through the use of internet and other digital formats.

With the application and use of e-resources in libraries, library staff are required to respond to the new environment for new roles in information acquisition, preservation and transfer. They need to be responsive to the growing information need. New kinds of competencies, skills and experiences are required beyond the traditional library settings (Chimah \& Nwokocha 2013). Several initiatives aimed at increasing the availability of e-resources have resulted in a significant increase in the number of institutions subscribing to the e-resources and initiatives like JSTOR, AGORA, HIRARI seeking to facilitate the coping technological changes.

\subsection{Academic Libraries.}

Reitz (2004) cited in Emenike, et al (2014) affirmed that academic library as an integral part of a College, University or other institutions of postsecondary education is administered to meet the information and research needs of its students, faculty and staff. Academic library is a type of library found in institutions of higher learning. He further explained that the main purpose of academic library is to support the objectives of its mother institution in the areas of learning, teaching, research and services.

Academic library is undergoing a fundamental shift away from merely providing access to scholarly literature towards assisting on its creation. The role of the library as the classic reader advisor has been resurrected as the need for intermediation and aggregation for users has become so critical in the face of information fulmination (Neal, 2012). Academic library is described by constant change and strategies in the face maintaining responsibilities and taking on new roles in the academy. Academic libraries are building more diverse and responsive service models leaving the sage at the desk mentality in favour of online interactions, scheduled consultations and in some cases point of need tutorials. In the digital age, academic libraries should upgrade their services and providing education of high quality by storing resources in various forms and maintaining easy accessibility for online use among academic community.

\subsection{Statement of the Problem}

The emergence of ICTs has brought about access to e-resources and has transformed the means of providing users' information needs. The quality of a library, traditional or electronic could be measured by the range of accessibility and application of its resources. A library with both physical and electronic information resources that is not accessible to users is insignificant. Academic libraries in some developing countries such as Nigeria and other Africa countries are striving towards catching up with the demand of the present digital era and thereby acquiring enormous e-resources while some are just trying to wake up. Despite the huge resources that are available in some academic libraries, it is observed that users are not making adequate use of it as a result of some inadequacies in their services. Some libraries are not even having enough e-resources due to lack of funds.

Several literatures in this field of study show that e-resources are used in academic libraries in developing countries by researchers, lecturers and students since academic library is an important source of information, but none explained the application of e-resources as a strategy for enhancing effective library services in academic libraries. This paper therefore focuses on the application of e-resources as a strategy for enhancing effective library services in academic libraries to the library users in order to meet their information and academic needs, the benefits of applying e-resources and the challenges facing academic libraries in performing their services.

\subsection{Review of Related Literatures}

Several investigations have been done on the application of e-resources for library services in different libraries. Due to quick proliferation in information acquisition and dissemination, libraries have adopted new policies for transformation in their collection development and service structures to improve the management of scholarly information Nirupma (2015). He noted that university libraries are used mostly for research work thus have to move towards digital resources which are less expensive and more useful for easy access. The consciousness and quality of available electronic resources is an important factor that led to the effective and efficient use of electronic resources. Talent and Kundai (2018) were of the opinion that traditional approach whereby a tutor was the only means of getting information is rapidly becoming obsolete as information continues to change in form and therefore recommended that universities should conduct awareness lectures on the benefits these facilities can bring to the students in the course of using them. 
Justina, et al (2016) submitted that libraries have evolved over time with technology. Recently, traditional libraries containing a large number of printed documents are being transformed to paperless libraries with the capacity for limitless volumes of information to be contained in digital formats. They noted that digital libraries are increasingly becoming part of school systems in many countries in Africa even though Africa is reputed to be late comer in the adoption of ICTs in education and that the continent is making strides to tap the benefits of the ICT-driven education sector. Part of the strides is to find out the challenges faced by the prime beneficiaries of technology and students.

Hungwa and Ramatu (2013) were of the opinion that $21^{\text {st }}$ century libraries have been transformed from traditional status of store house of information materials into information centers where ICTs are used to acquire, process, store, retrieve and disseminate information. The emphasis on print resources or total dependence on them is no longer reasonable because the print has a deficiency of assuming that everyone learns at the same pace and in the same manner and therefore not sufficient in today's high-tech multi-sensory approach to learning. With the rapid changes in the economic, political, social and technological environments, as well as the changes of higher education environments, academic libraries have undergone an extremely high pressure for innovation thus are in need of adjustments on existing services and developments of new services for dealing with challenges of management efficiencies and competitive advantages in an ever-changing world (Fu-Hsuan \& Pao-Nuan 2016).

The indispensable role of e-resources in libraries is to develop convenient library service delivery on daily basis, to support the user community in fulfilling their information needs by making available the maximum possible information resources, to assist the user in tracing non-print materials in libraries and helping them in attaining superior academic skills (Jasper et al 2016). Chimah and Nwokocha (2013) carried out an empirical study on motivation, challenges and strategies in the use of electronic information resources by postgraduate library users in South-east Nigerian federal universities, the study revealed that postgraduate students were motivated to use the electronic information resources (EIRs) in their university libraries because they found e-resources to be more informative, have easy access and use and as well save time.

In the Ghanian context, Maxwell, Edward and Rosemary (2015) were of the opinion that the impact of electronic resources indicated a significant positive relationship with usage among the users. The study recommended that intensive marketing strategies should be adopted to increase the usage of electronic resources in academic institutions in Ghana.

The literatures reviewed showed that several studies have been carried out to examine the application of eresources in the library services but none has emphasized the application of e-resources as a strategy for enhancing effective library services. The present study fills this gap.

\subsection{Application and Impact of e-resources in Academic Libraries}

Talent and Kundai (2018) described e-resources as collections of information in electronic or digital format that are accessed on an electronic version or format such as e-books, e-journals, encyclopedias, databases etc. They made mention of some types of e-resources that can be applied to library operations like:

Online databases

Institutional repositories

Advanced search engines and

Electronic past examination questions.

There are various areas in which e-resources can be used in library services such as: information subscriptions and ordering, publications, information storage, electronic mail services, acquisition of information materials. The essence of e-resources is in its power to help individuals and society achieve greater access to knowledge and ideas for the benefit of humanity. E-resources has led to improvement in the services in education and libraries because it ensures speed, effective and accuracy in the provision of up to date information. Vijayakumar and Sudhi (2011) noted that information technologies are expected to be used in library services for collection, processing, storage, retrieval and dissemination of recorded information and also it should be applied in areas such as:

- Library Automation 
- Library Management

- Library Networking

- Audio-video Technology and

- Technical Communication

E-resources is transforming the library system and as well as the way in which we view information resources. The future of library and information centers is bound up closely with the development of e-resources to enhance effective services. With the rapid development of electronic publishing, libraries are not only acquiring reading materials such as printed books and journals, but also arranging for providing access to various learning resources in electronic form (Anand, 2014).

Kelefa et al (2017) noted that it is clear that the print age is paving way to electronic information resources. They mentioned that several initiatives aimed to increase the availability of e-resources have resulted in significance increase in the number of African institutions subscribing to e-resources, initiatives like African Journal Online (AJOL), International Network for the Availability of Scientific Publications (INASP), JSTOR, HIRARI, AGORA.

\subsection{Benefits of Application of e-resources to Academic Library Services}

E-resources are very useful in today's libraries because of the quantity and quality of information they contain as well as the convenience of being able to access them anytime anywhere. Library information resources are better utilized when relevant facilities such as reading tables, chairs, book shelves, ICTs among others are available. The availability of facilities enhanced the ability of libraries to render necessary services to users.

The types of services in a library can be divided into three: The front-line services, the basic services and the ancillary services. The front-line services include Online Public Access Catalogue (OPAC), the library website and user educational programs. The basic services are the collections (physical and electronic), printing and computer facilities, library book borrowing and reference schedule while the ancillary services include facilities of indication of directions inside the library, suitable library business opening hours and provision of light reading materials. Many reasons have been attached to the selection of digital information resources over print resources by libraries and information centers which include: easy storage and sharing of information resources among users, ability to provide faster and easier access to information, saving space, retrieval of information from different sources (Justina et al, 2016). They pointed out some benefits that can be derived from applying eresources to library services which are:

- To increase productivity and provide better services to users

- To increase access to resources and facilitate new research

- To aid conservation/preservation and add value to the collection of the parent organization

- To support e-learning and online research

- To supplement traditional print resources and integrate multimedia libraries resources on a common platform

- To offer consistent access, give flexibility, provide enhanced capabilities for analysis and manipulation of information.

Anand (2014) also noted the following benefits of e-resources thus:

- Retrieval of e-resources is quicker than print resources

- Easy to search texts

- The collection available in electronic format can be of any media

- In electronic environment, the interaction between user and librarian is frequent

- E-resources search is easy because of its user friendly interface

- The electronic environment enables a library to integrate with other libraries and make use of their resources also

- Libraries provide access to very large amount of information resources

4.2

Challenges Associated with the Application of e-resources for library services

Many problems have been militating against the utilization of ICT -based library resources in some developing countries among which are: Non-availability and under-utilization of ICT library resources in libraries, underfunding, inadequate ICT infrastructures, donor-dependency, poor collections and high postage/delivery charges (Ani et al, 2016). They emphasized that the major problem is lack of fund. When there is no adequate funding, 
ICT infrastructure cannot be acquired and high-quality collections cannot be made. It is when funds are made available that library can as well make resources available and there can be proper application.

As we build the digital library of published and licensed content, digitized primary materials, open web resource and institutional records, we recognize the challenges of managing and preserving multimedia and dynamic information, increasingly integrated with services and dependent on software for effective access and use (Neal, 2012). The application of e-resources are facing some challenges. The challenges and problems that deter effective utilization of e-resources include:

- Slow internet connectivity

- Inability to access full text articles

- Unreliable power supply

- Inaccessibility of e-resources outside university premises due to IP address limitations

- Inadequate ICT infrastructure and

- Inadequate skills and knowledge (Kelefa et al 2017).

\subsection{Strategies for Enhancing Effective Library Services}

The development of effective information delivery system is an important component of university teaching and learning and modern technology greatly enhances the process. Libraries have been at the forefront of providing information resources and services to their respective communities of students, teachers and researchers to support academic and scholarly work. Sources of information available within academic libraries should promote active learning and contribute towards scholarly ability to think critically (Bassey \& Odu 2015).

Application of e-resources in library services cannot be over emphasized as it is one of the major strategies to enhance effective library services in this century. Academic libraries need to strategize on how to carry out effective and efficient library services in this digital era. To achieve this, the library environment should be made comfortable and pleasant to the users by making all necessary e-resources available and adequately apply them. Echezona (2005) cited by Ani et al, (2016) opined that availability and access to library resources will be enhanced if the following are taken into consideration:

- Provision of online materials in electronic format

- Provision of both printed and electronic information resources

- Updating the skills of library staff to enable them to help users in meeting their informational needs

- Improving the funding of the library to enable it to purchase and maintain needed information technology, books, journal and audio-visual resources.

According to Jacobs (2013) cited by Bassey \& Odu (2015), developments of ICTs are presenting rapid growth in the availability of electronic/digital information, subjects depositories and digital contents. With the evolving digital library services, online access to information, automation of library operations, establishment of library networking and resource sharing, the adoption of ICTs has no doubt transformed the traditional role of academic libraries and added to the advancement in the provision of fast and quality services.

\section{Conclusion}

Basic insights on the application of e-resources as strategies to enhance effective library services in academic libraries has been provided by this study. Many of the operations and services of academic libraries can be enhanced and more new services developed by applying proper e-resources in a suitable manner. Therefore, it can be concluded that e-resources add many benefits to the services of academic libraries and every client who is eagering to get a variety of information through electronic formats. To this the challenge of non-availability, inaccessibility of e-resources, inadequate ICT infrastructure and inadequate funding should be addressed.

\section{References}

Anand, Y.K. (2014). Types of e-resources and its utilities in library. International Journal of Information Sources and Services. 
Ani, V.A, Ani, E.O, Ugwu, C.O, Nwachukwu, A.I, Obianuko, J.C, Ndaji, G.I, \& Maduchie, E.E. (2016). Strategies for enhancing the utilization of information and communication technology (ICT)-based library resources in research. Library Philosophy and Practice, e-journal, 1-26. Retrieved from http://digitalcommons.unl.edu/libphilprac/1310.

Bassey, R.S, \& Odu, J.O. (2015). Evaluation of the extent of utilization of electronic library resources and services by undergraduate student in university of calabar library, calabar- Nigeria. Education Journal, 4(2), 82-89. Doi:10.11648/j.edu.20150402.15.

Chimah, J.N., \& Nwokocha, U. (2013). Empirical study of motivation, challenges and strategies in the use of electronic information resources by postgraduate library users in south-east Nigerian universities. International Journal of Library and Information Science, 5(11), 468-473.

Emenike, C.N, Obiora, K.U, \& Chibuzor, B.N. (2014). Evaluation of the use of university library resources and services by students of paul university, aroka, Anambra state, Nigeria. Library Philosophy and Practice (e-journal). Retrieved from http://digitalcommons.unl.edu/libphilprac/1147.

Fu-Hsan, C., \& Pao-Nuan, H. (2016). Barriers approach to innovation in academic libraries. Journal of Educational Media and Library Sciences, 53(3), 273-310. Doi:10.6120/JOEMLS.2016/0013.RS.AM.

Hungwa, S., \& Ramatu, T. (2013). The significance of electronic resources and digital library theories for skills development of library staff in nigeria. Library Philosophy and Practice (e-journal). Retrieved from http://diditalcommons.unl.edu/libphilprac/1001.

Jasper, M.M, Benard, O.G., Evans, N.M., \& Ezekiel, N.M. (2016). Strategies to enhance access and use of eresources by postgraduate students in selected university libraries in kisii county, Kenya. International Journal of Academic Library and Information Science, 4(8), 203-207. Retrieved from http://www.academicresearchjournal.org/IJALIS/index.htm.

Justina, N.E., Charles, O.O, \& Chidinma, M.N. (2016). Users' perception of the facilities, resources and services of the MTN digital library at the university of Nigeria, nsukka. Library Philosophy and Practice (ejournal). Retrieved from http://digitalcommons.unl.edu/libphilprac/1390.

Kelefa, M., Emmanuel, E., \& Esther, N. S. (2017). Utilization of e-resources to support teaching and research in higher learning institutions, Tanzania. University of Dar es Salaam Library Journal, 12(2), 98-123.

Maxwell, A., Edward, A., \& Rosemary, A. (2015). Impact of electronic resources and usage in academic libraries in ghana: evidence from koforidua polytechnic and all nations university college, ghana. Journal of Education and Practice, 6(33). Retrieved from www.iiste.org.

Neal, J.G. (2012). Opportunities for systematic change in the academic research library: elements of the postdigital library. Insights, 25(1), 92-97. doi:10.1629/2048-7754.25.1.92.

Nirupma, C. (2015). Use of e-resources in panjab university library, chandigarh. International Journal of Digital Library Services, 5(4).

Talent, M., \& Kundai, O. (2018). An investigation on e-resource utilization among university students in a developing country: a case of great Zimbabwe university. South African Journal of Information Management, 20(1). http://dx.doi.org/10.4102/sajim.v20i1.860.

Vijayakumar, A., \& Sudhi, S.V. (2011). Application of information technology in libraries: overview. International Journal of Digital Library Services, 1(2). 